\title{
農村地域住民の多項目血液検査からみた検診成績 と検査の選択上の問題点について
}

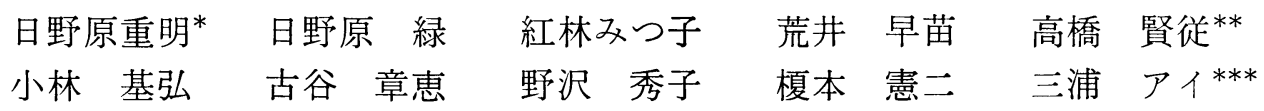

\section{はじめに}

現在わが国における死因別死亡率は，脳血管障害が第 1 位, 悪性新生物が第 2 位, 心疾患が第 3 位となってい る。そのため保健所及び市町村で行なわれている健診 は, 胃ガン, 子宮ガンなどのガン検診と, 脳血管障害, 心疾患発見のための成人病健診である。

昭和44年から47年にかけて脳血管障害による死亡率が 全国平均の 2 倍を越える市町村の中から 12 県 132 地区を 対象として，厚生省が行なった成人病健診の検査項目 は, 血圧測定, 問診, 尿検査, 心電図, 眼底検査であっ たが，これらの検査項目から発見できないものとして， 貧血, 糖尿病, 肝機能障害, 腎不全などがある。本研究 では従来の検查項目に SMAC による22項目の血液化学 分析と Hemalog による血球及び血色素分析並びに食後 の血糖值の高めの者に対する糖負荷試験を追加すること により, 従来の検查項目では見落とされる異常値の頻度 を調べ，今後の成人病健診における検査項目について考 察することを目的とした。

\section{対象及び方法}

次に調査対象並びに研究方法について述べると, 対象 となった神奈川県足柄上郡中井町は人口 8,500 人で, 近 年の宅地化の傾向により町の一部は都心へ通勤する人々 のベッドタウンとなっているが，大部分は野菜，果実， 酪農などを営む農村である。中井町における脳血管障害 による死亡率は全国平均に比べてかなり高く，また神奈 川県下で最高となっている。今回の調査は昭和 54 年 5 月 7 日から11日までの 5 日間, 35歳から64歳までの在宅者 を対象とし，保健所によって施行された住民健診である が，その内容を多項目にすることにより，見落とされる 疾患ができるだけ少なくなるよらな方法で行なった。対 象者は535名（男性147名, 平均年齢49.7歳, 女性388名, 平均年齡 46.5 歳）で，身体測定，問診，血圧測定，尿検 査, 心電図, 胸部 X線撮影の他に, SMAC による 22 項 目の血液化学分析, Hemalog による血球及び 血色素分 析, 並びに食後の血糖值の高めの者に対して糖負荷試験 を実施した。以上の検査結果をコンピュータによりデー 夕処理を行ない, 性別, 年代別, 疾病の自覚の有無別に \footnotetext{
and its Problems

* (財)ライフプランニングセンター

** 神奈川県足柄上保健所

$* * *$ 神奈川県中井町
}

Comparison of the Results of Routine Adult Health Screening and Multiphasic Blood Tests Done for the Inhabitants of a Rural Village
行なった。

\section{結 果}

WHO の基準によると，高血圧と判定された者は男性 群では $25.8 \%$ で女性群の $7.5 \%$ に比べ，約 3 倍といら高 い值を示している。高血圧と判定された者の内，無自覚 者は男性群では63.2\%, 女性群では $44.8 \%$ に達した。貧 血の基準を男性は血色素が $11.9 \mathrm{~g} / \mathrm{dl}$ 以下，女性は 11.5 $\mathrm{g} / \mathrm{dl}$ 以下としたところ，男性群では $1.4 \%$ ，女性群で $18.9 \%$ となり, 男性群では全例が無自覚者, 女性群では 80.8\%が無自覚者であった。女性群を年代別にみると， 40〜44歳において貧血が最も多く 3 割弱に達している。 食後 1 時間の血糖值が $140 \mathrm{mg} / \mathrm{dl}$ 以上の者に対して行な った糖負荷試験により診断された糖尿病は男性群で 9.5 $\%$ ，女性群で $2.8 \%$ で，新たに糖尿病と診断された者は 男性群で $64.4 \%$, 女性群で $54.5 \%$ となった。GOT, GPT の值が $40 \mathrm{u} / 1$ 以上で肝機能障害と判定された者は, 男性 群ではそれぞれ $5 \%$ 前後，女性群ではそれぞれ $3 \%$ 前後 となり，男性群にやや肝障害が多い結果となっている。 この内, 肝機能障害を自覚していた者は全例の 1 割にす ぎなかった。尿素窒素またはクレアチニンによって腎不 全と判定された者は全体の $2.6 \%$ で，この内腎不全を自 覚していた者は $1.4 \%$ であった。尿酸值が $8 \mathrm{mg} / \mathrm{dl}$ 以上 の高尿酸血症の者は, 男性群で $6.8 \%$, 女性群で $1.8 \%$ で, 男性群は女性群の約 4 倍の頻度を示した。この内, 男性群において痛風治療中が $10 \%$, 降圧剂の影響による と思われる者が $20 \%$ で，女性群の高尿酸血症の約 6 割は 降圧剤の影響によるものとみなされた。以上の疾患を頻 度の多い順に述べると, 男性群では高血圧, 糖尿病, 高 尿酸血症, 肝機能障害, 腎不全, 貧血で, 女性群では貧 血, 高血圧, 肝機能障害, 糖尿病, 腎不全, 高尿酸血症 の順となった。

\section{考 察}

現在住民健診あるいは老人健診では厚生省の前述の項 目の他に, 血色素, 血糖值, コレステロール值の測定を 加えた健診が行なわれているが，我々が行なった多項目 検査と比較すると, 肝機能障害 $3.8 \%$, 腎不全 $2.6 \%$, 糖 尿病 $4.7 \%$ を見落とす結果となる。若干の経済的な問題 があるとはいえ，人間ドックに準じた健診を行ならこと ができ，精度管理も緻密にされている多項目検査をもっ と広く採用し，これらのデータが主治医によって活用さ れれば効率の良い健診といえよう。尚, 健診によるデー タの判定には, 問診による受診者の服薬状況や病識の有 無などを確めることがデータの正しい判定及び指導上き わめて意義深いものと考光る。 